\title{
The Origin of the Volunteer Medical Staff Corps in 1885
}

\author{
Brigadier TW Glenister, \\ CBE, TD, DSc, PhD, MB, BS, MRCS, LRCP, L/RAMC(TA)
}

On 1st April 1985 the Territorial Army Medical Services celebrated the Centenary of the official establishment of the Volunteer Medical Staff Corps which was to develop from small beginnings into the Royal Army Medical Corps of the Territorial Army.

The study of the origins of the Volunteer Medical Services of the Army brings to light a remarkable set of coincidences.

A military surgeon develops an interest in First Aid and produces the manuscript of a manual on the subject but dies on an African Campaign before it can be completed and published. He has however entrusted the manuscript to a friend who is an Aberdeen graduate and who has migrated South to Charing Cross Hospital. This Aberdonian, while at University, had developed a friendship and shared lodgings with a native of Banffshire whom he eventually attracted to the surgical staff of the Charing Cross Hospital.

This young man from Banff was encouraged by his old friend of Aberdeen days to take on the task of bringing to publication the draft first aid manual of the deceased Army Surgeon. This he did with an enthusiasm that fired his imagination to establish a group of first aiders drawn from the ranks of the medical students at his hospital.

In his spare time our young surgeon devoted some of his unbounded energies to serving the medical needs of the London Scottish Volunteers and so became aware of the lack of medical support for the Army's Volunteer Units. He found a ready solution by marshalling the resources already available to him in the shape of first aid oriented medical students at his hospital and with them laid the foundations of what are now the Territorial Army Medical Services.

The following account is based on and quotes extensively from James Cantlie, A Romance in Medicine by Neil Cantlie (one of his sons) and George Seaver published in 1939 and The Quality of Mercy, the Lives of Sir James and Lady Cantlie by Jean Cantlie Stewart (his grand-daughter) published in 1983.

James Cantlie first saw the light of day on 17 January 1851 at Keithmore in the Parish of Mortlach by Dufftown in the County of Banff. He commenced his university career in the Faculty of Arts at the King's College of Aberdeen University in October 1866 and during his early days struck up a friendship with John Mitchell Bruce, a more senior student who was studying medicine. They came to share the same lodgings and it

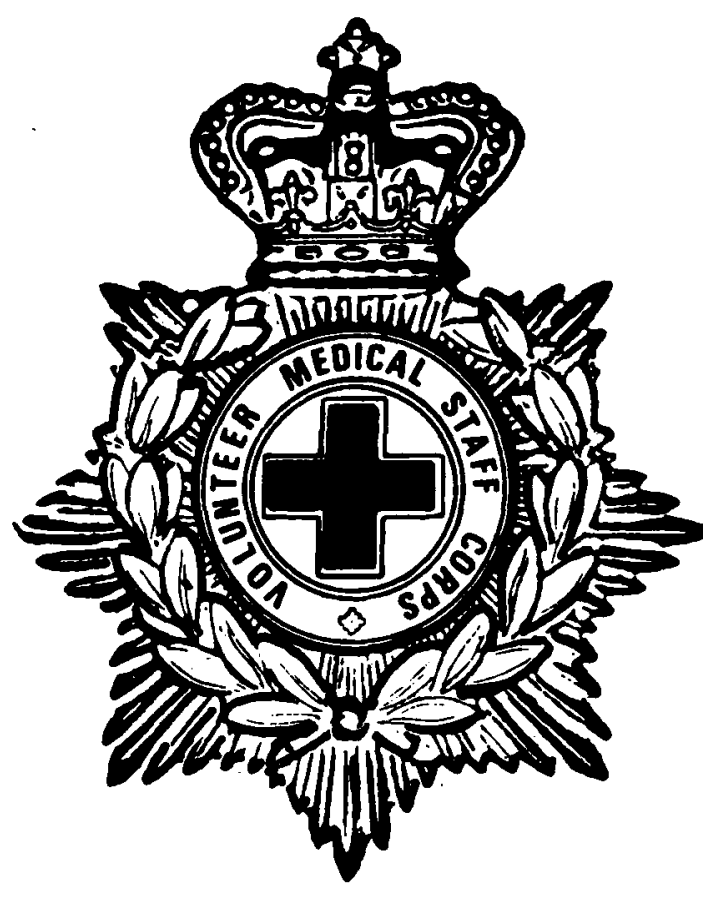


James Cantlie was appointed Demonstrator of Anatomy, at the Medical School of Charing Cross Hospital in 1873, the year he qualified MB CM of Aberdeen. He was appointed Assistant Surgeon in 1878 and became Senior Assistant Surgeon in 1880, the year in which he developed an interest in first aid.

Mitchell Bruce, an Aberdonian on the staff of Charing Cross, had attracted Cantlie there and Surgeon-Major Peter Sheppard, also an Aberdonian and friend of Mitchell Bruce, was preparing a text-book on "First Aid to the Injured" for the St John Ambulance Brigade. Ordered unexpectedly to the Zulu War, Sheppard called on Bruce and dumped some pages of the unfinished manuscript on the table and, after explaining he was leaving for South Africa within the hour, he asked Bruce to keep the papers for him, or to finish the book if he never returned.

Sheppard was killed at Isandhlwana, gallantly sacrificing his life for a comrade, and the manuscript was left on Cantlie's hands by Bruce.

His interest now thoroughly aroused, Cantlie began to give public lectures on First Aid at St John's Gate, the Headquarters of the St. John Ambulance Brigade. The success of the lectures was proved by the wave of enthusiasm which, spreading from St John's Gate as a centre, swept over London. Lectures and meetings were arranged at various centres, while a ripple even penetrated to the strongholds of officialdom in Whitehall, for we hear of him addressing an ambulance class at the Admiralty!

In 1882 Cantlie joined the London Scottish Volunteers as an Assistant Surgeon, and delighted in the chance to wear the kilt once more, whilst Easter marches and camps gave him a welcome change from the atmosphere of the wards and the dissecting room. This appointment was fraught with far-reaching consequences and was to lead him to the most important issue of his life, for it was during a camp on Wimbledon Common that he first made the acquaintance of Miss Mabel Barclay Brown, his destined wife. Her father, Robert Barclay Brown, was in the Regiment, a largeframed and large-hearted Scotsman with curling beard, magnificent in the kilt. On July 30th 1884 , his marriage to Miss Barclay Brown took place at the Church of St Martin's in the Fields. She proved to be, in the truest possible sense of the word, a helpmate for him.

In March 1883, Mr Andrew Maclure of the London Scottish Volunteers, who realised the importance of placing the responsibility for organisation and training of stretcher bearers upon the Volunteer Surgeons, asked Cantlie to deliver first-aid lectures to a class of volunteers. He also invited him to witness the subsequent stretcher drill. "While I was instructing and watching stretcher drill", wrote Cantlie,

"I was struck with the usefulness such instruction would be to medical men. The medical curriculum gave us no such knowledge, the lifting of patients, the carriage of the injured by road and rail formed no part of our instruction. One night whilst trudgingz westwards through sleet and slush after the class wasक over, the idea of teaching medical students stretcher drill came into my mind. Gradually the vista opened.응 I saw those medical students applying theiron knowledge to the movement of patients in hospital. saw these young men scattered throughout the? country ... carrying with them a practical knowledge of ambulance (sic.) and becoming Volunteer음 Surgeons and instructors of stretcher bearers in the $\frac{\bar{c}}{7}$ battalions to which they belonged. I believed also $I_{\unrhd}^{\mathbb{Q}}$ saw a connecting link whereby the surgeons might be gathered together into a coherent body instead of existing as separate units; the genesis in fact of the Volunteer Medical Association."

Cantlie proceeded to invite the Regular Army⿳亠二口犬 Sergeant Instructor to come to Charing Cross Hospital and teach the students. He told them of his plan and asked them to join the drill. Seventy-two joined that afternoon and for the first time orders of "Attention", "Lift Stretcher", "Lower Stretcher" echoed aroußd ¿ Charing Cross. The drills took place three times a we $\mathbb{G}_{k}^{\infty}$ and their popularity increased as well as their efficiency.

One day, at the end of his anatomical demonstratiofi, $\vec{c}$ Cantlie was presented a card bearing the name of Surgeon Major Evatt from the Royal Military Acader at Woolwich. Evatt had experience of Field Ambulaneev work in the Afghan Wars and had been sent by Maclike $\overrightarrow{0}$ because he too was interested in developing a voluntegroo ambulance movement. The two men repaired so $_{0}$ Romano's and there, over a steak, decided to callō meeting of the Volunteer Surgeons in the Board Roc of Charing Cross Hospital. This meeting resulted in theō formation of the Volunteer Medical Association withő General W G Hunter as Chairman, Surgeon Majorฉ Evatt (later Surgeon General Sir George Evatt) as Vice- $\overrightarrow{0}$ Chairman and Cantlie as Secretary. By June, fifty-one 3 surgeons had joined and all the medical schools had representatives.

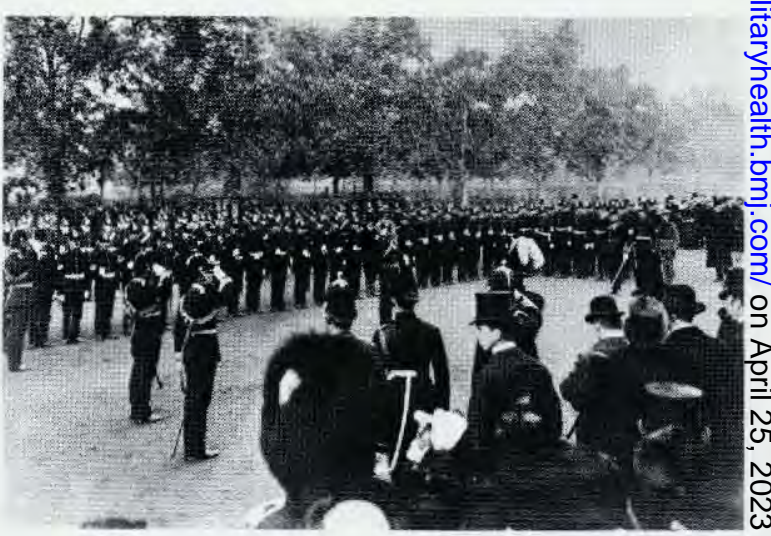


However, Charing Cross was still the only hospital with medical students as volunteers. Cantlie obtained permission for his students to drill within St George's Barracks under the eye of the Guards and procured an ambulance wagon, stretchers, and tents for a parade on Wimbledon Common.

Cantlie records that

"As time went on, the month of July came round, I was anxious that the trained body of bearers should be seen by the public and by someone in authority. After much reflection, I fixed upon no less a person than Lord Wolseley, and set about to scheme how to get hold of him. It is the custom at Charing Cross Hospital to hold the annual distribution of prizes about the month of July, and at the committee meeting held beforehand I got one of the teachers to propose that Lord Wolseley should be asked to preside. This was unanimously agreed to, and I had succeeded so far. I then unfolded my plan, namely that the distinguished soldier should inspect the hospital stretcher-bearers at St George's Barracks before distributing the prizes. All the plans answered admirably and the day for inspection arrived.

During the interval, drills were frequent and exact, but I was fraught with anxiety as to the result of the day's work, not only as to how we should execute our movements, but also as to the effect on the men I wanted to get at, namely the staff of the London hospitals. It happened that in 1883 the Charing Cross cricket team was of excellent calibre; so good, in fact, that they were to play the final for the cup against King's College. To my chagrin it turned out that the match was to be played at the Oval on the very day fixed for the inspection by Lord Wolseley. To the Oval every one of the students was going as player or spectator, and the ranks of my company seemed about to be bled to the last man. I was in despair, and bethought myself of what could be done. I fell back on a very simple plan, but a plan that has often succeeded before. I appealed to their appetites, and asked the whole of the company, seventy-two in number, to luncheon at a restaurant in close proximity to the parade ground. The importance of the work outbalanced in my mind the value of a horde of luncheons, and the result of the day's work I deemed to be full of vital consequence to the future of the VMSC. Not only did I take the step mentioned, but I went to the cricket match, and at the adjournment for luncheon at the Oval, reminded the members of the company that their luncheon was also ready and the omnibuses outside the ground were in readiness to convey them thither. Thus I did secure their attendance. And how we had to run the gauntlet of the afternoon's inspection and the criticism in St George's barrack square. The students' 'uniform' consisted of jackets, low hats, and Red Cross brassards worn on the left arm - not much for a young lad to be proud of, but the drill and the discipline ha told, the ranks were well dressed, and the smart appearance of the company called forth unanimou praise. From such recruits one would expecf excellent results; young, hopeful and intelligent, we clad and well shod, they looked capable of anything Neither gaudy trappings nor martial music:

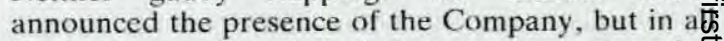
the freshness of youth the infant company seemed $\overrightarrow{0}$ justify its birth, and give token of great possibilities if the near future....

Lord Wolseley arrived on the ground argi inspected the ranks, which were drawn up in oped order. There was little to inspect as the men had neither uniform, arms, nor equipment. Such 2 क anomalous squad I am sure never before passed the distinguished soldier's criticism. No wonder that he first question was 'Who are these men? Are they 공 John Ambulance? Are they Volunteers? Do the belong to the Red Cross Society?' No - was the answer to each question. I could merely say, as vice passed down the ranks, that they were medic $\vec{f}$ students of Charing Cross Hospital trying to impers themselves in ambulance drill. A few min afterwards, however, I was able to tell him? if scheme for the formation of a Medical Staff Cogps for the Volunteers, and that it was thought wis commence with the medical students, as likel form the future officers of the Corps; and that sh they become battalion surgeons they would be to take up their appointments with a full knowle्ल of their duties. In shorter time than I have take्g 90 write the above statement, Wolseley's keen earsatg sharp intellect took in the statements, and gras their meaning. He foresaw the importance of ti⿱丷天) work. He mentioned the difficulties of creating a now department, the necessity of a special grant. In $\bar{\phi}_{1}$ word, the future of the Volunteer Medical Sta Corps, its possibilities and difficulties, lay like open book before his clear perception....

But of all this parade, what was to be the outcom Before the day was over, it was made known to me Evatt, ever on the alert, was instilling the principle of the idea into likely men. The men he wanted to got at were the staffs of the London hospitals which haj medical schools attached. Whilst the members of tige Company were binding up imaginery wounds on th drummer boys lent by the Guards as patients, the all-important men were being initiated by Evatt. S్ well did his words tell that more than one hospita! surgeon left the ground asking, 'Why should nญెt every medical school have an ambulance company?ô

We knew then that the day was won, that all the work so far was a gain and that the future of the Cors. was a question of push and time. I am loth to pats with this, the really greatest moment in the history sy the Corps. It was all so novel and fresh; the larfs crowd of interested spectators; the successful soldiry 


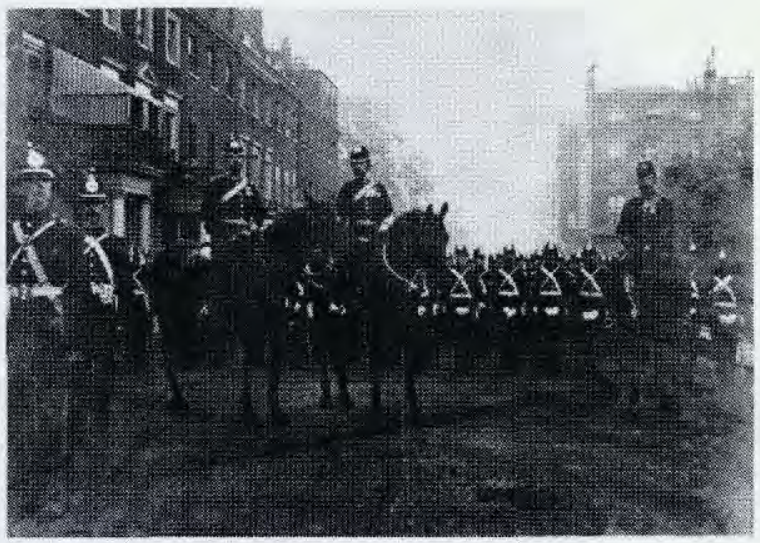

fresh from his 1883 Egyptian triumph; the success of the parade; the glorious weather which favoured it; the hopefulness of the future of the movement; all combined to render it a period on which memory loves to dwell,"

Lord Wolseley proved to be one of Cantlie's staunchest allies. At the distribution of prizes in Charing Cross Hospital Medical School after the inspection, Lord Wolseley spoke in eulogistic terms of the parade. What, in Cantlie's view, was more important still, he unfolded the idea to the large assembly present, and next morning the Volunteers throughout the Kingdom read the words 'Volunteer Medical Staff Corps' in the press.

The significance of this publicity was not lost on Mitchell Bruce, who remarks in his diary of July 8th -

"This movement which promises to be of national extent and importance originated entirely with Cantlie. He has fought the battle single-handed and we now can say that he has won it."

As with all new movements, success was not certain until finance was assured. Offers were not long in coming. On 25 July Sir William McCormac sent for Cantlie and told him that the National Aid Society had granted $£ 250$ towards the training of ambulance companies. Cantlie now realised with gratitude that, should the Government not receive the Corps into the Volunteers, the NAS would allow them to enlist under its auspices and train an ambulance of medical men and hospital assistants ready to help in national emergencies. 'The Globe' newspaper welcomed such a plan, pointing out that the 'funds of the NAS, instead of lying idle, would be usefully employed in supplying the ambulance material for the bearer companies, which the new organisation seems able to enlist.' Cantlie knew however that, while appreciating the moral and financial support, the volunteer surgeons would wish to stand, if it were possible, side by side with their regular brethren in the Army Medical Department.
In October 1883 Evatt put into action his plan to raise recruits from medical students of other London hospitals by means of a lecture tour. This brought into the movement University College, the London Hospital, St Bartholomew's, St Thomas's, the Middlesex and Guy's - St Mary's joining the movement when it became established as a Corps. During the winter, meetings of the Association were held on 13th February; Sir Trevor Lawrence, M.P., introduced a deputation of Volunteer Surgeons, civilian doctors, teachers in London medical schools and members of the ambulance association to Lord Hartington, Secretary of State for War. The deputation said that, while the Volunteers possessed regimental surgeons, they had no medical department or hospital corps to organise divisional bearer companies or field hospitals. The deputation stated that there would be no difficulty in starting such a medical corps which would stand in the same relation to the volunteer forces as the Army Medical Department did to the Regular Army, but that it would need a capitation allowance and ambulance training material. Lord Hartington expressed his favour, but promised nothing until Parliament debated the Army estimates. He allowed the deputation to hope however, that the idea would be favourably entertained in the next session, and he spoke so encouragingly that Cantlie and the other members left with firm hope of recognition and confidence in the future.

While awaiting a decision from those in authority, the obvious next step was to bring together the seven? hospital companies in which there was an understratum? of feud and rivalry. The trouble was, as Cantlie recounts, that

"Every Hospital wanted their own separate company, and, with but a few exceptions, the prejudice seemed insurmountable, not only with the men themselves, but with the members of the Hospital staff at many Schools, who had set their faces against amalgamation. Under these circumstances, I believed that a uniform was the only means of breaking down the barrier and bringing about cohesion in one battalion. But how was the money for such a uniform to be raised? I happened in these straits to come across Mr McGill of the firm Pipe and McGill in Maiden Lane. I informed him we wanted a uniform and asked him to supply patterns of cloth similar to that worn by the Medical Staff Corps of the Army. Gradually it came about that I made a proposal to this effect; (like all north-east Scots Cantlie thought it bad manners to ask directly for something; instead he cast a fly and waited for the fish to rise) I said that my object was to get Government recognition for the Corps, and in the meantime I wanted them clad in uniform for two reasons; first to induce the various hospital companies to come together, and secondly to make so good an appearance that the Government dare not 
refuse us recognition. I pointed out to $\mathrm{Mr} \mathrm{McGill}$ that the sum I meant to spend for the good of the nation was more than I dared risk, and that, did we not get recognition, it was a question of my going bankrupt on principle. I believed that, did the public come to know how such a catastrophe came about, it was certain a question would be asked in the House and the matter brought up. Mr McGill saw my arguments, believed their cogency, and pushed on the clothing of the men with all speed. Nor has he lived to repent it. He got, thereby, an introduction to every Medical School in London and extended his private business accordingly."

The uniform was modelled on the Army pattern, but there were some points on which there was discussion: the Regular Army Medical Staff Corps undress uniform cap was the ordinary forage cap worn by the line regiments, while the scientific Corps, Engineers and so forth wore the round cap.

"The War Office, I was told, would not allow the round cap. It was not allowed for the Regulars, and therefore would be vetoed for the Volunteers. However, as we were not yet under military authority we got the round caps and wore them. When the time came for laying them aside the same story was repeated, and then came the tussle. I pointed out to the authorities that ... its not being allowed in the Regular Army was no reason why the Volunteers should not have their just due. That rather than give way, we would enrol ourselves under the National Aid Society.... Whatever the reason may have been the round cap was allowed us. As the summer wore on, the drills were attended by more men in uniform, until only recruits appeared in civilian dress at Battalion Drill. There was, however, still friction; the old separate hospital notion had not died out. Companies had to be equalised in Battalion Drill and men had to fall out of their own hospital ranks and join those of another with fewer men. Hospitals with large numbers asked what was the good of getting sufficient men together to form a Company when at parades their numbers were bled to supply the efficiency of less energetic officers and students of other hospitals."

Cantlie decided that what was needed was

"to inculate into the students a higher loyalty, an esprit de corps more binding than even their respective hospitals could prove. ... . In such circumstances my mind turned again to an inspection by some prominent person as the only means of diverting the thoughts of the students from themselves and infusing the battalion with a feeling of common interest. Who was the great one to be procured? . . . After Lord Wolseley's inspection, when we were elated with the success of the parade, I had determined to infringe further on his Lordship's good nature, and accordingly wrote asking him if he could bring it about that the bearer company he hat inspected could go to Windsor and appear before Her Majesty the Queen. Lord Wolseley had replied wit his wonted courtesy that he did not think the time haof arrived for such a step, but that on a future occasiono when we were better equipped, he would consider ito

I therefore wrote now to Lord Wolseley. concerning the matter, and reminded him of mip request and of his reply the previous year. Day afteo day went past and no reply came. The middle of Julo was approaching and still I heard nothing. A few days? more and the fulfilment of my scheme would b $\$$ impossible owing to the breaking up of the Schoolso The horizon was dark, when it was suddenly lit up by a letter from Lord Wolseley announcing that he ha $\Phi$ forwarded my letter to Windsor, but that $\mathrm{He} \overrightarrow{\mathrm{e}}$ Majesty the Queen found it impossible to grant mo request for the present year. However, at Heल. Majesty's request, he had sent on my letter to He Royal Highness, the Princess Louise, Marchioness of Lorne, to whom he had spoken on the subjeçu previously. Accordingly I had a letter on July 16th from the ADC announcing that Her Royal Highwess had consented to see the Hospital companies, \$upo that the only day possible before the 24 th when the Schools broke up was the following day, the 17 thet 2.30 p.m. Here was a dilemma! The intimation to Her Royal Highness was coming was most gratifyiag but the time! The men were not in barracks to called together by a bugle. They were attendingat. different hospitals and living in houses and lodgings $\$ 00$ scattered all over London. It was 9 p.m. on the 1 tot when we got the news, but as moments were valuad 18 we did not discuss the matter, but set to work ant dispatched letters and telegrams in all directions. enlisted a number of Charing Cross Hospital studento for the evening and their willing hands did giant 8 work. At 1 a.m. I went round the various daily papers and had it announced in the notices for the day that Her Royal Highness, Princess Louise, would be present in St. George's Barracks to see thot Ambulance Companies paraded for inspection. The inspection came off, not entirely satisfactorily, but the men looked well in their new uniforms and wer through their work creditably. There was a fair gathering of onlookers and after the parade th $\$$ Marquis addressed the Companies and in a capita speech gave an account of the possibilities of ambulance work. With a hearty cheer in honour of. Her Royal Highness the inspection ended and onc 8 again the members dispersed for their holidays."

Cantlie was now told by the War Office that it would be necessary to find lay recruits, for a Corps formed onl of medical students would not meet with approval since they would only be in the ranks for about two-and-a-haff? years. 'But where to find such recruits?' Cantlie askef himself. 
"I had lectured for a good many years in ambulance work at the Birkbeck Institute (now London University) and got well acquainted with a few of the more prominent students to whom I unfolded my plan. With enthusiasm they set to work to spread the idea, so that within three weeks fifty men were enrolled. After careful thought I decided to take advantage of the cordial atmosphere of a smoking concert to unfold the news. I therefore asked the Birkbeck Company to come to the students' room of Charing Cross Hospital Medical School half an hour before the time of the concert and to stay to the concert afterwards. As the medical students assembled with their friends from the other Schools they found stretcher drill proceeding, but did not recognise the Birkbeck men. I enlightened them and tried to get the onlookers to admire the drill, but my announcement was received coldly. The students began to whisper among themselves and retired out of view to converse. . . At last one or two spoke out and said that were any but medical men to belong to the contemplated Corps they would resign. I knew this was coming, it was no good pointing out to the lads of seventeen that the Corps was an impossibility unless laymen belonged to it. . . . When the drill was over and the concert began it was difficult to get harmony. The Birkbeck men sat in one corner, the medical students in another. At last one of the former gave a capital song and proved an excellent musician; affairs went on more smoothly and at the end of the concert the two sets of men were favourably impressed with one another."

Thus the most critical moment in the life of the Corps was successfully passed and a further company of lay recruits was later enrolled at Woolwich. Meanwhile, the War Office had also advised that the movement must include hospital medical schools and universities all over the country and Evatt had set out on a lecture tour to bring these students in as recruits. Cantlie accompanied Evatt on almost all of these tours. Owen's College, Manchester, and the Yorkshire College, Leeds, were accomplished in an afternoon and evening, with the two men returning on the midnight express. Edinburgh, Aberdeen, Dublin and Belfast involved more time. In Edinburgh, the Principal Medical Officer of the Forces in Scotland was Lord Wolseley's brother, and the medical students already made up two of the finest companies of the Queen's Edinburgh, of which the Lord Advocate was the Colonel. This did not prevent him from encouraging the students to join the new Medical Corps which he promised to present with an ambulance wagon. The result was 'a magnificent body of men in the blue uniform of the VMSC'. Leaving for Aberdeen, Cantlie's alma mater, at $5.00 \mathrm{a} . \mathrm{m}$., they met a committee already formed to raise a branch of medical students for the Volunteer Medical Association. At Trinity College, Dublin, where Evatt had trained, the doctors were well received and Evatt's words drew much applause on account of their remarkable powers of address and persuasion. Cantlie records that as a result of this visit the medical students of Trinity enrolled as a company of the VMSC,' a great achievement, as Ireland had no volunteers and at Queen's College, Belfast, there was the same satisfactory result. A further company was also raised at Maidstone. Press reports in these towns commented on Evatt's talks on military ambulance and Cantlie's lectures on peace-time first aid, in which he pointed out how much civilian doctors could learn from the military about the movement of patients and organisation of hospitals, and 'The Lancet' made particular mention of the evils of separating military and civil medicine.

The last qualifying step having been taken, Cantlie was told in February that a grant for the VMSC was in the Army estimates for the year and throughout March he was in the War Office daily. On 3 March a request was made to General Hunter from the Medical Department of the War Office to nominate an officer for the command of the new Corps and Hunter returned Cantlie's name. On 1 April 1885 the Volunteer Medica Staff Corps was gazetted with a constitution of foures companies, an adjutant, a quartermaster and a surgeon commandant.

On the evening of Wednesday 1 April 1885, the day

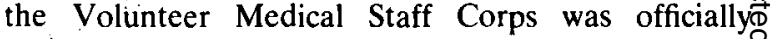
gazetted; the outpatient department and board room of Charing Cross Hospital were in effect converted into a military equipment store containing greatcoats, side arms, belts, water bottles, haversacks. The men were 'sworn in' in the Board Room. After assembling in fronto of the hospital, the Corps marched to the Chapel Royal, Savoy, where the Chaplain in an earnest address and service, baptised the infant corps and sent it forth with his blessing for a long life of usefulness.'

One last obstacle had to be overcome, the procuring of a band. Cantlie decided that, although the Regulars still had no band, the VMSC who, according to the Press after a military camp at Aldershot in August, showed considerable musical prowess, would endeavour to secure one. "At their first annual inspection," he wrote, "they had marched past to the 'tuck o' the drum' and the effect was not exhilarating and the marching not steady".

"I made up my mind to have a band by next year. I found out, however, that permission for its formation was not likely to be forthcoming; in fact there was not the slightest hope. The Medical Staff of the Army had eight years before subscribed between $£ 8000$ and $£ 9000$ for a band, but when they asked permission from the War Office the petition was refused. Nothing daunted, I not only found a bandmaster, but also a band ready to hand, and it was merely a question of clothing them in our clothing and the thing was settled. Again, however, the War Office gave me no hope. Director General Crawford was 
afraid the request was futile. General Elkington could find no precedent and the door seemed shut in my face. All the time I was getting the band into uniform. As a last resort I determined to go to the War Office, and with a map of the distribution of the Volunteer Forces in Great Britain, which I had drawn up, to boldly face Lord Wolseley, bent on attaining my end. The map I exposed to his scrutiny and in a few seconds he gave me valuable suggestions which I duly noted. I asked if the Volunteer Corps were allowed bands officially, and, when this turned out to be the case, I ventured to add that the VMSC was a Volunteer Corps, therefore we could have a band. 'Certainly', said Lord Wolseley; but, on further thought, he added, 'I cannot see what a doctors' corps wants a band for - and besides, the Duke of Cambridge won't allow it. He would not give it to the Regulars'."

Cantlie described to Lord Wolseley how useful the band would be at inspections, concerts, theatricals and social gatherings, pointing out that the Volunteers were only held together by the unity of good fellowship and that the band would act as a focus, whilst, in addition, a band in a hospital encampment would 'enliven the monotony of hospital life and cheer the weary patient'. To Cantlie's delight Lord Wolseley suddenly said, 'Well, put in your application and I will back it up'. "That very afternoon," says Cantlie,

"I sent in the application to the Director General, who promised to forward it. It was certainly urgent, as the day was Tuesday, and on Monday 1 had arranged that the band should appear and play at $S \frac{5}{6}$ James' Hall, when our prize-giving took place. Onf this occasion the War Office put through the worlo speedily, for by Friday I had permission to raise band. It was already at hand, and when the Director: General and General Elkington came to the prizes? giving on Monday, they were confronted by the band in the uniform of the Corps playing them welcome음 Not only had we got our band, but, more importanth still we had established the principle of a Medica员 Corps having a band, and in 1887, although I wass away in China, it would have been a great satisfaction to me to have been present at Aldershot when the VMSC band played the Regulars to Church."

In due course the Regulars acquired a band which was? maintained voluntarily by the officers until 1938 when ie was officially recognised.

Now in 1985, the Regular RAMC Band has been disbanded and ironically the musical tradition of the Corps has reverted back to the Territorial Army in the form of the Band of 257 (Southern) General Hosp RAMC(V). And what of the line established 95 Cantlie's original band of keen medical students? It cagn? be traced "genealogically" right down from the origiōal Volunteer Medical Staff Corps, through units of Gie Territorial Force and later Territorial Army, to present day 217 (London) General Hospital RAMC(Z)

\section{NOTICE TO SUBSCRIBERS}

The Journal is published three times a year, in February, June and October. The annual subscription (payable in advance) is $£ 10.00$, to include the Army Medical Services Magazine, or $£ 8.00$ for the Journal alone, post free in both cases. A single copy costs $£ 3.00$.

All communications relating to subscriptions, including notification of change of address, should be sent to the Manager, Journal RAMC, RAM College, Millbank, London SW1P 4RJ. Cheques and bankers' orders should be payable to Journal RAMC and crossed "Williams \& Glyns".

\section{NOTICE TO ADVERTISERS}

Space orders should be sent to Combined Service Publications Ltd., P.O. Box 4, Farnborough, Hampshire GU14 7LR. Blocks and/or Copy should be forwarded to the same address to arrive by the first day of the month preceding issue, publication dates being February, June and October of each year.

Advertising Rates and Technical Details are as listed in British Rate and Data. 